\title{
IDENTIFIKASI Myxobolus sp. PADA FAMILI CYPRINIDAE DENGAN METODE MOLOKULER DI PROVINSI JAWA TIMUR DAN JAWA TENGAH
}

\author{
Ayuda Dyah Nurekawati*1, Gunanti Mahasri ${ }^{1}$, Muchammad Yunus ${ }^{2}$ \\ ${ }^{1}$ Prodi S2 Bioteknologi Perikanan dan Kelautan, Sekolah Pascasarjana Universitas Airlangga \\ ${ }^{2}$ Fakultas Kedokteran Hewan Universitas Airlangga \\ Kampus C Mulyosari - Surabaya, 60115 Telp. 031-5992785 \\ e-mail: *11ayudadyah@gmail.com
}

\begin{abstract}
Abstrak
Myxobolus sp menginfeksi insang dari ikan common carp dan golfish, parasit ini membentuk kista pada lembar insang ikan, sehingga akan menghalangi proses penyerapan oksigen. Diagnosa infeksi Myxobolus sp berdasarkan identifikasi myxospora yang terbentuk pada insang famili Cyprinidae, menggunakan teknik wet mount dan teknik polymerase chain reaction pada $18 \mathrm{~S}$ rDNA sebagai identifikasi spesies myxospora yang lebih cepat. Data morfometri yang digunakan untuk mengidentifikasi Myxobolus sp pada famili cyprinidae yang berasal dari Jawa Timur dan Jawa Tengah yang menunjukkan adanya varian perbedaan bentuk dan ukuran spora. Secara morfometri ukuran Myxobolus sp yang ditemukan menginfeksi Ikan Komet (Carassius auratus) pada umumnya spora lebih panjang 1-2 $\mu \mathrm{m}$, namun secara keseluruhan tidak menunjukan perbedaan yang signifikan. Primer yang digunakan untuk amplifikasi merupakan primer spesifik pada $18 \mathrm{~S}$ region untuk mendeteksi Myxobolus sp dengan menggunkan Primer ERIB1 dan ERIB10 (Barta et al.,1997). Berdasarkan hasil pemeriksaan PCR diperoleh fragmen DNA di 2034 bp, sehingga secara Molekuler semua organ sampel yang digunakan pada penelitian ini menunjukkan positif terinfeksi Myxobolus sp
\end{abstract}

Kata kunci: Identifikasi Myxobolus sp pada famili Cyprinidae

\begin{abstract}
Myxobolus sp infect common carp and goldfish gill, this parasite forming cyst on gill sheet and inhibity protected the absorbing process of oxygen. Myxobolus sp infected can be diagnosed quickly by identification of myxospora that is formed on gill, by using wet mount technic and polymerase chain reaction at $18 \mathrm{~s}$ rDNA as identification myxospora species.Used morfometri data to identify Myxobolus sp at Family Cyprinidae from east java and center java which seen that shown there were various differences at shape and size of spora. By using morfometri size of Myxobolus sp were found to infect comet fish (Carassius auratus) were generally longger 1-2 $\mu \mathrm{m}$, spore than over all koi fish did not show a significantly difference.We
\end{abstract}

JBP Vol. 18, No. 2, Agustus 2016-Ayuda Dyah Nurekawati

172 
used specific amplification primer 18s region to detect myxobolus by using ERIB1 and ERIB10 (Barta et al.,1997). Based on the results obtained PCR fragment DNA at $2034 \mathrm{bp}$, all organ samples in this study were positively infected by Myxobolus sp.

Keywords: Identification Myxobolus sp on family Cyprinidae

\section{PENDAHULUAN}

Indonesia memiliki perairan tawar yang sangat luas dan berpotensi besar untuk usaha budidaya berbagai macam jenis ikan air tawar. Secara ekonomis, usaha budidaya ikan air tawar sangat menguntungkan karena ikan ini memilki nilai ekonomi yang tinggi serta sangat mendukung bagi pemenuhan gizi masyarakat dan iklim memungkinkan ikan hias tersebut dapat bereproduksi sepanjang tahun.. Selain itu, serapan pasar ikan air tawar tidak hanya terbatas di dalam negeri, melainkan hingga pasar Internasional (Cahyono 2000).

Famili Cyprinidae merupakan famili ikan dengan genus terbesar yang sebanyak 210 genus dan 2010 spesies (Nelson, 1994). Meyden (1991) menyatakan bahwa distribusi famili Cyprinidae sangat luas, yaitu hampir diseluruh dunia. Ikan dari famili Cyprinidae dapat dijadikan ikan hias dan sebagian lagi dijadikan ikan konsumsi, terutama ikan yang berukuran besar. Famili Cyprinidae yang biasa di konsumsi antara lain ikan mas (Cyprinus carpio), ikan wader (Puntius binotatus), ikan nilem (Osteochilus hasseltii), ikan koan atau grasscarp (Ctenopharyngodon idella) dan ikan tawes (Barbonymus gonionotus). Sedangkan famili Cyprinidae yang dijadikan sebagai ikan hias antara lain : ikan maskoki, ikan koi, ikan komet (Carassius auratus) dan ikan botia (Chromobotia macracanthus).

Salah satu peluang ekspor perikanan adalah ikan hias yang cukup diminati di pasar nasional maupun pasar internasional. Nilai ekspor ikan hias pada tahun 2010 naik 10\% dari US\$ 10 juta tahun 2009, menjadi sekitar US\$ 11 juta ditahun 2010. Kenaikan itu menyebabkan peluang pasar ikan hias seperti ikan koi mengalami peningkatan permintaan (Wijaya 2011).
Tingginya permintaan pasar menyebabkan meningkatnya budidaya ikan air tawar. Keberhasilan dalam kegiatan budidaya ikan air tawar untuk menghasilkan ikan yang mempunyai daya jual yang tinggi masih sangat rendah. Hal ini disebabkan kurang tersedianya benih ikan yang memadai baik secara kualitas maupun kuantitas. Ikan yang baik secara kualitas adalah yang tahan terhadap serangan penyakit dan tahan terhadap perubahan kualitas air. Pada umumnya, para pembudidaya ikan di Indonesia dalam kegiatan budidaya hanya berdasarkan pengalaman dan ketekunan. Untuk memenuhi kebutuhan pasar maka perlu dikembangkan upaya yang tepat sehingga dapat menghasilkan ikan air tawar yang baik secara kualitas maupun kuantitas. Salah satu upaya mendapatkan benih ikan yang baik yaitu dengan menjaga kualitas air dalam media pemeliharaan. Penurunan kualitas air dapat diakibatkan oleh beberapa faktor antara lain mengendapnya sisa pakan dan sisa metabolisme di dasar perairan, jika dibiarkan terlalu lama akan berubah menjadi amonia yang bersifat toksik bagi ikan yang ada di perairan tersebut (Alifuddin dkk., 2003).

Lingkungan air yang mengalami penurunan kualitas akan mengakibatkan aktifitas agen penyebab penyakit meningkat sehingga ikan mudah terserang penyakit. Penyakit menyebabkan penurunan kualitas dan kuantitas produk yang berdampak pada kerugian ekonomi bagi pembudidaya. Di antara agen infeksi yang merugikan adalah myxosporea dari genus Myxobolus. Myxobolus terdiri dari beberapa spesies dan merupakan parasit umum pada berbagai jenis ikan air tawar dengan penyebaran hampir di seluruh dunia (Alifuddin dkk., 2003).

Menurut Kepmen. No. 26/KEPMENKP/2013 bahwa Myxobolus cerebralis dan 
Myxobolus koi masuk dalam daftar Hama Penyakit Ikan Karantina (HPIK) golongan I. Jenis ikan yang sering terinfeksi Myxosporea di Indonesia antara lain benih ikan mas, tawes, sepat. gurami dan tambakan, inang umumnya dari jenis famili Cyprinidae, Labirinth dan Salmonidae.

Hobir (2006) menemukan Myxobolus cyprinii, Myxobolus koi dan Myxobolus artus di Magelang Jawa Tengah, pada insang ikan koi (Cyprinus carpio) berdasarkan bentuk dan ukuran spora. Myxobolus sp juga ditemukan di daerah Ngrajek kabupaten Magelang pada tahun 2006 dengan prevalensi mencapai 91\%, (Obing, 2006). Myxobolus koi di Magelang Jawa Tengah sering menyerang pada benih ikan, sehingga hal tersebut menyebabkan benih lebih rentan terinfeksi Myxobolus koi daripada ikan dewasa. Infeksi Myxobolus koi dapat menyebabkan kematian sekitar 50\% dari populasi (Mulyana et. al. 1990).

Rukyani (1990) melaporkan di Indonesia Myxobolus koi menyebabkan masalah serius pada budidaya ikan koi (Cyprinus carpio) dengan tingkat mortalitas sebesar $60-90 \%$. Menurut laporan petani ikan koi di Blitar, wabah penyakit ini dari tahun 2009 sampai dengan 2012 masih menyerang benih ikan mas berukuran 3-5 cm dengan tingkat kematian 90\% (Lu'lu'in et al., 2012). Berdasarkan wilayah Pemantauan Daerah Sebar Hama Penyakit Ikan (HPI)/Hama Penyakit Ikan Karantina (HPIK) di Balai Karantina Ikan, Pengendalian Mutu dan Keamanan Hasil Perikanan Kelas I Surabaya I serangan Myxobolus mulai tahun 2012 sampai dengan 2014 dilaporkan Myxobolus koi menginfeksi benih ikan koi dengan ukuran 3$16 \mathrm{~cm}$, yang berlokasi di Desa Kemloko, Kecamatan Nglegok, Kabupaten Blitar, dengan kematian mencapai 90\%. Selain dapat menyebabkan kematian, parasit myxozoa juga dapat menurunkan nilai ekonomis dari ikan hias air tawar. Penyebaran parasit ini terjadi karena perpindahan parasit dari ikan yang terinfeksi ke ikan sehat, baik secara langsung maupun melalui inang antara pada fase tertentu dari siklus hidup parasit tersebut.

Myxobolus koi menginfeksi insang dari ikan common carp dan golfish dengan ciri-ciri terdapat nodul putih atau agak kemerahan atau bahkan berwarna merah pada jaringan insang. Parasit ini membentuk kista pada lembar insang ikan, sehingga akan menghalangi proses penyerapan oksigen (Paperna, 1992 and Egusa, 1992). Myxosporea yang menyerang insang ikan mas antara lain Myxobolus koi, M. toyamai, Thelohanellus caliporis, sedangkan Myxosporea yang menyerang daging ikan adalah Myxobolus artus (Dana and Maskur 1991).

Genus Myxobolus memiliki jumlah spesies yang banyak, sekitar 500 spesies Myxobolus yang menginfeksi ikan, dimana 444 diantaranya telah berhasil dicatat Lom dan Dykova (1992). Diagnosis penyakit ini dapat dilakukan dengan melihat gejala klinis, namun identifikasi Myxobolus sampai ke tingkat spesies tidak mudah. Klasifikasi Myxobolus didasarkan pada bentuk spora yang merupakan struktur yang paling jelas. Tahapan vegetatif menunjukkan beberapa karakteristik penting untuk klasifikasi, meskipun analisis sekuensing 18S rDNA atau daerah gen lain direkomendasikan untuk identifikasi sampai tingkat spesies (Camus and Griffin, 2010).

Parasit Myxobolus sp yang berkembang dengan cepat dapat mengakibatkan terjadinya perubahan genetika yang berpengaruh terhadap terjadinya mutasi terhadap sistem kekebalan tubuh inang. Faktor kemungkinan perubahan tersebut bisa disebabkan karena lingkungan, kualitas air, distribusi dan manajemen budidaya. Tingkat mutasi yang tinggi menghasilkan keragaman genetik yang tinggi pula. Sebagian besar mutasi bersifat merusak dan menyebabkan kerugian (Mahy dan Marc, 2010).

Berdasarkan uraian di atas perlu dilakukan penelitian untuk membuktikan Myxobolus sp pada famili cyprinidae yang ada di provinsi Jawa Timur dan Jawa Tengah. Penelitian ini bertujuan untuk mengidentifikasi perbedaan spesies Myxobolus pada famili Cyprinidae berdasarkan analisa secara molekuler, sehingga dapat dijadikan dasar menetapkan kebijakan untuk menurunkan resiko 
terjangkitnya Myxobolus pada budidaya ikan di Indonesia.

\section{METODE PENELITIAN}

Kegiatan penelitian ini dilakukan di Balai Karantina Ikan Pengendalian Mutu dan Keamanan Hasil Perikanan Kelas I Surabaya I, selama 3 bulan dimulai dari bulan Maret 2016 sampai Mei 2016. Pengambilan sampel ikan cyprinid yang terserang Myxobolus dilakukan di wilayah Jawa Timur (Blitar, Kediri, Tulungagung), dan di wilayah Jawa Tengah (Magelang dan Semarang).

Bahan yang digunakan PCR antara lain : Silica Extraction Kit (GeneReach Biotechnology Corp), Master Mix (KAPABiosytems, KK5103), ddH2O/Nuclease Free water (PCR Grade Water) (Ambion,AM9937), Agarose gel (1\% Gel O-Shooter) (LE Agarose, R9012LE500gr), DEPC $\mathrm{H}_{2} \mathrm{O} \quad$ (GeneReach Biotechnology Corp), GT Buffer (GeneReach Biotechnology Corp), Etanol 70\%, TAE Buffer, Ethidium bromide (Maestro, MR031203), Marker (Molecular Weight Ladder) (KAPA, KK6302), template DNA, primer Forward ERIB1 dan Reverse ERIB10, Barta et al.,1997 (Gene).

Bahan yang digunakan sebagai pengawet spora Myxobolus koi antara lain : aquadest, entellan (Merck), etanol absolut (Merck), lugol solution (UPT BPPTK LIPI), Giemsa (Merck) dan minyak emersi (Merck).

Peralatan yang digunakan dalam uji coba ini adalah gunting, botol sampel, skalpel, pinset, beker gelas, cawan petri, gelas objek, cover slip, nampan plastik, mikroskop, timbangan analitik, microtube, mikropipet eppendorf $(10 \mu \mathrm{l}, 200 \mu \mathrm{l}, 1000 \mu \mathrm{l})$, tip mikropipet, vortex, tabung eppendorf $(0,2 \mathrm{ml}$, $0,5 \mathrm{ml}, 1,5 \mathrm{ml})$, timbangan analitik, hot plate, minispin, thermal cycler T100 (Bio-Rad), tabung erlenmayer (Iwaki Pyrex), pellet pastle, microcentrifuge tube, mikropippet, vortex, UV doc (Alpha innotech), polaroid camera, frizer lemari es dan inkubator, Dry Block Thermostat (Biosan), DNA/RNA UVCleaner Box (Biosan).
Jumlah sampel yang diambil berdasarkan Cannon (2001) sebanyak 150 ekor pada ukuran benih dengan ukuran $\pm 3-10$ $\mathrm{cm}$ dan penentuan besaran contoh uji pada suatu populasi semua sampel diambil secara acak. Ikan koi yang mempunyai gejala klinis insang membengkak dan operkulum tidak dapat menutup sempurna dengan jumlah nodul terbanyak akan dipilih sebagai kolam sampel. Sampel yang terinfeksi Myxobolus diberi es batu untuk sesegera mungkin di simpan di dalam freezer atau direndam etanol $95 \%$ (Senapin, et.al. 2007)

Identifikasi pengamatan morfologi Myxobolus dilakukan dengan memeriksa adanya spora yang memiliki polar kapsul pada spesimen segar. Nodul yang berwarna putih pada tubuh ikan disayat dan isinya dibuat smear pada gelas obyek lalu dikering anginkan, selanjutnya diwarnai dengan larutan Giemsa/Lugol's iodine solution 10 - 15 menit. Kemudian dibilas dengan air dan dikeringkan diudara. Setelah kering, spesimen di mount dengan menggunakan entelan yang sebelumnya telah ditetesi dengan xylol yang berfungsi sebagai clearing agar spesimen terlihat jernih saat diamati dibawah mikroskop (Lom dan Dykova, 1992). Identifikasi dilakukan dengan mikroskop Olympus CX31 Binokuler Tri Coumpound perbesaran lensa 400x dan 1000x. Pengamatan ini dilakukan untuk menentukan bentuk spora dengan pengukuran morfologi spora seperti panjang, lebar dan ketebalan spora serta panjang dan lebar polar kapsul (Handajani dan Samsundari, 2005).

Pemeriksaan dengan Metode PCR (Polymerase Chain Reaction), saat ini deteksi parasit telah berkembang menggunakan material DNA/RNA yaitu PCR (Polymerase Chain Reaction). Keunggulan PCR terletak pada kecepatan, spesivitas dan sensivitasnya dalam mendeteksi mikroorganisme patogen, menjadikan teknik ini sebagai pilhan untuk deteksi ataupun diagnose penyakit. PCR merupakan teknik cepat untuk mengamplifikasi fragmen DNA spesifik secara in vitro dengan menggunakan 2 primer untai tunggal pendek. Penelitian ini menggunakan Primer untuk amplifikasi 
merupakan primer spesifik pada $18 \mathrm{~S}$ region untuk mendeteksi Myxobolus sp dengan menggunkan Forward ERIB1 5, ACCTGGTTGATCCTGCCAG - $3^{\prime}$ dan Reverse ERIB10 5, CCTCCGCAGGTTCACCTACGG - 3' (Barta et al.,1997). Adapun tahapan PCR adalah:

\subsection{Ekstraksi DNA.}

DNA diekstraksi dengan

menggunakan Silica Extraction Kit (Gene) dari jaringan yang diawetkan dalam larutan etanol absolut. Masing-masing sampel jaringan insang yang teridentifikasi Myxobolus dimasukkan ke dalam mikrotube 1,5 ml, tambahkan dengan 900 ul GT Buffer, haluskan dengan menggunakan pastle penggerus, sentrifugasi pada kecepatan 12000 rpm selama 3 menit. Larutan lapisan diambil 600 ul dipindahkan ke dalam dalam mikrotube $1,5 \mathrm{ml}$ yang baru, masukkan silica $40 \mathrm{ul}$, vortex agar homogen dan disentrifugasi pada kecepatan 12000 rpm selama 15 detik (tidak boleh lebih dari 20 detik). Setelah di sentrifugasi buang larutannya, cuci pellet silica dengan 500 ul GT Buffer, vortex sampai pellet silica membentuk suspensi, di sentrifugasi pada kecepatan 12000 rpm selama 15 detik (tidak boleh lebih dari 20 detik), buang larutannya, tambahkan $1 \mathrm{ml}$ ethanol $70 \%$ untuk mencuci pellet silica dan vortex sampai pellet silica membentuk suspensi. Sentrifugasi pada kecepatan $12000 \mathrm{rpm}$ selama 15 detik (tidak boleh lebih dari 20 detik), buang etanol, gunakan mikropippet untuk mengambil ethanol yang masih tersisa, $\begin{array}{lllll}\text { tambahkan } \quad 1 \quad \mathrm{ml} & \mathrm{ddH}_{2} \mathrm{O} & \text { untuk }\end{array}$ meresuspensikan pellet silica, vortex sampai pellet silica membentuk suspense. Inkubasi pada suhu $55^{\circ} \mathrm{C}$ selama 10 menit, homogenkan dengan di vortex selanjutnya disentrifugasi pada kecepatan $12000 \mathrm{rpm}$ selama 2 menit, kemudian pindahkan 500 ul dari larutan atas ke dalam mikrotube baru dan siap digunakan.

\subsection{Amplifikasi.}

Amplifikasi bertujuan untuk memperbanyak DNA dari template. Primer yang digunakan dalam uji PCR antara lain: primer Forward ERIB1 5' -
ACCTGGTTGATCCTGCCAG - 3' $(2-20)$ dan Reverse ERIB10 5, CCTCCGCAGGTTCACCTACGG - 3' (2079 - 2059), Barta et al.,1997. Total volume campuran reaksi PCR sebanyak $25 \mu \mathrm{I}$, yang terdiri dari Master Mix (KAPABiosytems, KK510). Primer Forward $2 \mu \mathrm{I}$, Primer Reverse $2 \mu \mathrm{I}$, Template DNA $2 \mu \mathrm{I}$, Nuclease free water $19 \mu \mathrm{I}$. Amplifikasi dilakukan dengan setting suhu Predenaturasi pada $94{ }^{\circ} \mathrm{C}$ selama 2 menit, dilanjutkan denaturasi $94{ }^{\circ} \mathrm{C}$ selama 1 menit, annealing $58^{\circ} \mathrm{C}$ selama 1 menit, extension $72^{\circ} \mathrm{C}$ selama 1 menit 30 detik sebanyak 35 siklus dan ditambah final elongation $72^{\circ} \mathrm{C}$ selama 5 menit. c). Elektroforesis.

\subsection{Elektroforesis.}

Hasil amplifikasi DNA diperiksa menggunakan $1,5 \%$ gel agarose direndam menggunakan TAE buffer $1 \mathrm{X}$. Lubang pada gel diisi secara berurutan dengan marker, 10 $\mu \mathrm{l}$ hasil amplifikasi dan blanko kontrol. Proses elektroforesis dilakukan selama 45 menit dengan voltase 100 volt. Gel direndam dalam buffer yang ditambahkan $\mathrm{SyBr}$ save (Invitrogen) selama 15 menit. Gel diletakkan pada gel documentation, diamati di bawah sinar UV dan didokumentasikan.

\subsection{Analisis data}

Hasil konvensional (morfologi), molekuler Polymerase Chain Reaction (PCR).
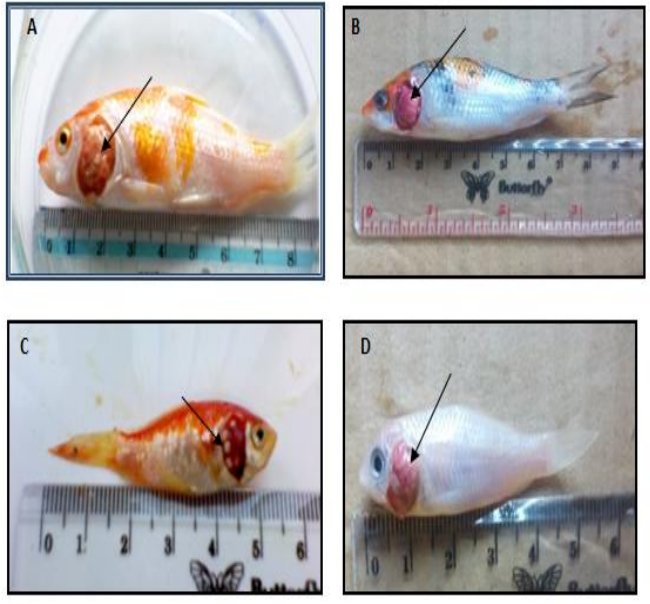
Tulungagung; C. Ikan komet (Carassius auratus) Kediri dan D. Ikan koi (Cyprinus carpio) Kediri.

\section{HASIL DAN PEMBAHASAN}

Hasil pemeriksaan Myxobolus dilakukan secara mikroskopis dan molokuler terhadap spora yang terdapat pada nodul di insang ikan cyprinid yang diambil dari beberapa sentra budidaya yang ada di Jawa Timur yaitu wilayah Blitar, Kediri dan Tulungagung, sedangkan di Jawa Tengah wilayah sentra budidayanya yaitu Semarang dan Magelang. Beberapa sampel ikan yang terinfeksi Myxobolus sp yang diperoleh dari wilayah Jawa Timur dan Jawa Tengah yang diambil sebagai isolat yaitu Blitar (ikan koi 4 isolat); Kediri (ikan komet 2 isolat, ikan koi 2 isolat); Tulungagung (ikan koi 4 isolat); Semarang (ikan komet 2 isolat, ikan koi 2 isolat); Magelang (ikan mas 2 isolat, ikan koi 2 isolat). Adapun contoh gambar ikan yg terinfeksi Myxobolus sp di Jawa Timur dan Jawa Tengah dapat dilihat gambar 1 dan gambar 2 dibawah ini:
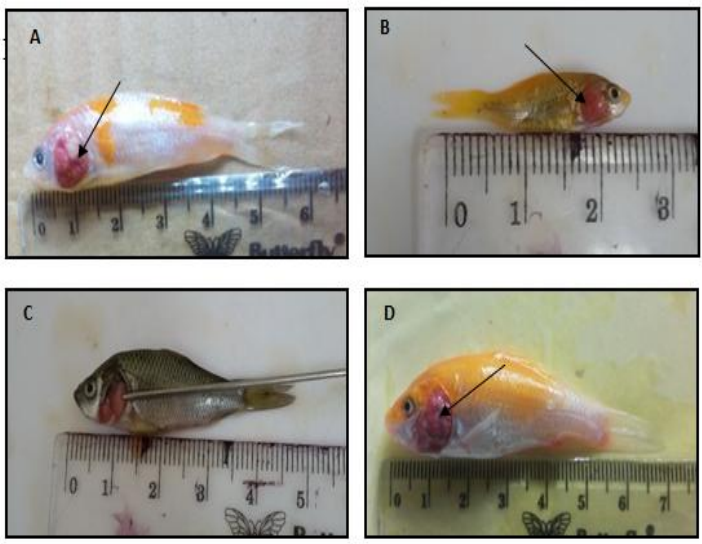

Gambar 1. Gejala klinis ikan Cyprinid yang terinfeksi Myxobolus sp. pada insang di wilayah Jawa Timur. A. Ikan koi (Cyprinus carpio) Blitar; B. Ikan koi (Cyprinus carpio)
Gambar 2. Gejala klinis ikan Cyprinid yang terinfeksi Myxobolus sp. pada insang di wilayah Jawa Tengah. A. Ikan koi (Cyprinus carpio) Semarang; B. Ikan komet (Carassius auratus) Semarang; C. Ikan mas (Cyprinus carpio) Magelang dan D. Ikan koi (Cyprinus carpio) Magelang.

Parasit Myxobolus sp yang ditemukan pada bagian insang ikan Cyprinid yang ada di wilayah Jatim dan Jateng memiliki perbedaan karakteristik, bentuk dan ukuran spora. Bentuk spora pyriform, pipih pada anterior dan melebar pada bagian posterior. Filamen polar melingkar, pada suatu garis lurus yang memanjang yang berporos pada polar kapsul. Pada bagian posterior dari spora mempunyai karakteristik dan bentuk yang sama yaitu adanya vakuola iodinophilous. Identifikasi secara mikroskopik hasil pewarnaan menggunakan mikroskop Olympus CX31 Binokuler Tri Coumpound perbesaran lensa 1000x.

Pewarnaan Giemsa pada spora Myxobolus sp dari ikan Cyprinid di Jatim dapat dilihat pada Gambar 3, sedangkan pewarnaan Lugol iodine pada spora Myxobolus sp wilayah Jateng dapat dilihat pada Gambar 4. 


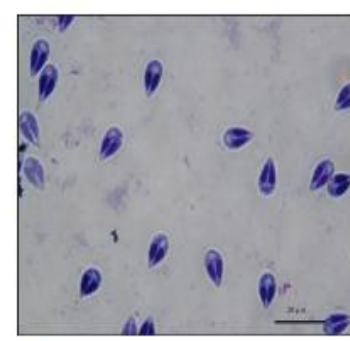

A
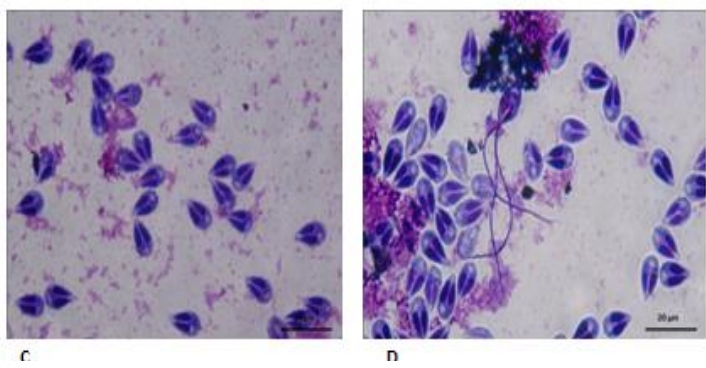

Gambar 3. Pewarnaan Myxobolus sp. dengan Giemsa perbesaran 1000x pada insang. A. Ikan koi (Cyprinus carpio) Blitar; B. Ikan koi (Cyprinus carpio) Tulungagung; C. Ikan komet (Carassius auratus) Kediri dan D. Ikan koi (Cyprinus carpio) Kediri.
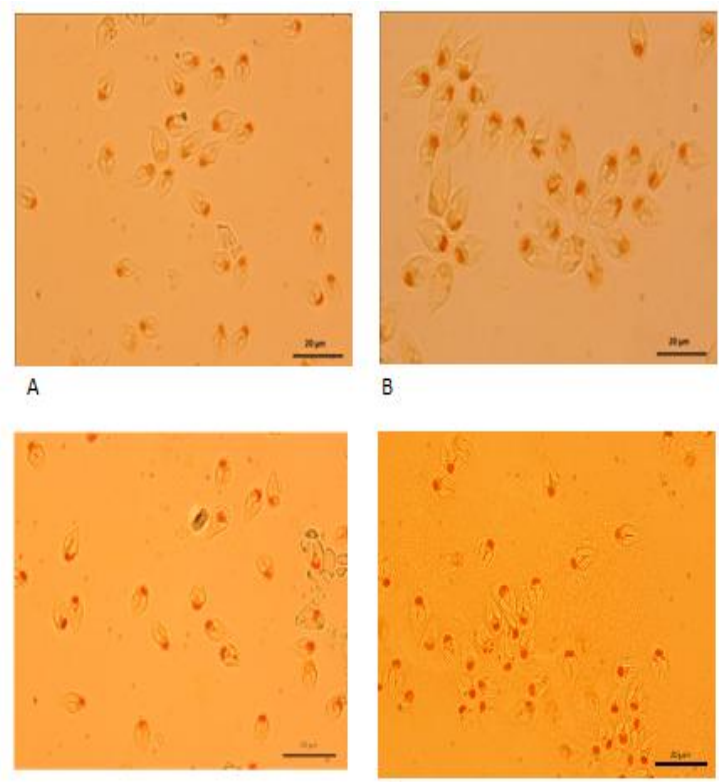

C

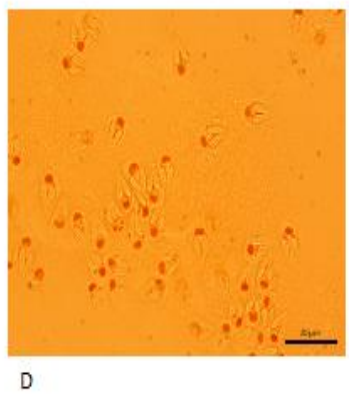

Gambar 4. Pewarnaan Myxobolus sp. dengan Lugol iodine perbesaran 100x pada insang. A. Ikan koi (Cyprinus carpio) Semarang; B. Ikan komet (Carassius auratus)
Semarang; C. Ikan mas (Cyprinus carpio) Magelang dan D. Ikan koi (Cyprinus carpio) Magelang.

Myxobolus sp. yang morfologinya mirip dengan Myxobolus toyami, Myxobolus longisporus dan Myxobolus koi, diisolasi dari insang ikan koi (Cyprinus carpio), sering dijumpai pada kolam ikan hias. Plasmodia yang besar ditemukan diantara lamella, yang menyebabkan kerusakan parah dan menyebabkan gangguan pernafasan. Beberapa kunci karakteristik lebih mendekati dengan Myxobolus koi. Jika dilihat dari bagian katubnya, spora tampak memanjang dan bentuknya pyriformis dengan posterior yang bulat, panjang $15.4(14.5-16.5) \mu \mathrm{m}$ dan lebar 8.3 (7.1- 9.0) $\mu \mathrm{m}$. Polar kapsul berbentuk pyriformis dan panjang $10.1(9.0-10.9) \mu \mathrm{m}$ dan lebar $3.1(2.5-3.5) \mu \mathrm{m}$. Polar filament membentuk 10 kumparan tegak lurus kebawah sepanjang sumbu dari bentuk spora (Alvin et al., 2010). Adapun contoh pengukuran spora Myxobolus sp berdasarkan hasil pewarnaan dengan lugol iodine dibandingkan dengan literatur dapat dilihat pada gambar 5 .

Gambar 5. A. Pengukuran spora Myxobolus sp berdasarkan pewarnaan menggunakan Lugol iodine; B. Pengukuran spora Myxobolus sp berdasarkan literatur a. panjang spora, b.lebar spora, c. tebal spora, d. panjang polar kapsul, e. lebar polar kapsul. Sumber (Kabata, 1985).

Identifikasi Myxobolus sp. yang menginfeksi insang famili Cyprinidae di Jatim dan Jateng pada spora Myxobolus sp. memiliki sedikit perbedaan karakteristik, bentuk dan ukuran. Secara mikroskopik ukuran spora dari famili Cyprinidae di Jatim dapat dilihat pada Tabel 1.

Tabel 1. Hasil identifikasi spora Myxobolus sp. pada organ insang ikan koi (Cyprinus carpio) Blitar; ikan koi (Cyprinus carpio) Tulungagung; ikan komet (Carassius auratus) 
yang berbeda menggunakan suhu Gradient untuk mendapatkan pita DNA tunggal pada tamplate yang akan diuji, sehingga anneling yang didapat berkisar $55^{\circ} \mathrm{C}$ dan $59^{\circ} \mathrm{C}$.

Selanjutnya divisualisasi melalui proses elektroforesis. Hasil elektroforesis dari suhu Gradient pada anneling 56,2 (G), 57,3 (F), 58,7 (E), 59,8 (D) dapat dilihat pada Gambar 5.

Hasil ekstraksi dilanjutkan dengan amplifikasi menggunakan suhu annealing $55^{\circ} \mathrm{C}$ diperoleh pita DNA tunggal (single band) produk PCR pada sampel 5, 6, 19, 20 Gambar 6. Elektroforesis produk PCR dengan annealing $59^{\circ} \mathrm{C}$, menunjukkan bahwa pita DNA tunggal (single band) nomor sampel 1, 2, 3, 4, 7, 8, 9, 10, 11, 12, 13, 14 (Gambar 7) dan 15, 16, 17, 18 (Gambar 8).

Berdasarkan beberapa tahapan annealing yang dilakukan,sebagai penentu dalam penelitian ini diambil suhu annealing $55^{\circ} \mathrm{C}$ pada nomor sampel 5, 6; dan annealing $59^{\circ} \mathrm{C}$ pada nomor sampel $1,2,3,4,7,8,9,10$, 11, 12, 13, 14, 15, 16. Hasil dari elektroforesis produk PCR yang positif Myxobolus sp.

Primer yang digunakan untuk amplifikasi merupakan primer spesifik pada 18S region untuk mendeteksi Myxobolus sp dengan menggunkan Forward ERIB1 5' ACCTGGTTGATCCTGCCAG - 3' dan Reverse ERIB10 5, CCTCCGCAGGTTCACCTACGG - 3' (Barta et al.,1997). Berdasarkan hasil

\begin{tabular}{|l|l|l|c|c|}
\hline $\begin{array}{c}\text { No. } \\
\text { Sampel }\end{array}$ & \multicolumn{1}{|c|}{ Tempat } & \multicolumn{1}{|c|}{$\begin{array}{c}\text { Jenis } \\
\text { Ikan }\end{array}$} & $\begin{array}{c}\text { Temperatur } \\
\text { Annealing } \\
\left({ }^{\circ} \mathrm{C}\right)\end{array}$ & Hasil \\
\hline 1 & Blitar(Jatim) & Koi & 59 & + \\
\hline 2 & Blitar(Jatim) & Koi & 59 & + \\
\hline 3 & Kedir(Jatim) & Komet & 59 & + \\
\hline 4 & Kedir(Jatim) & Koi & 59 & + \\
\hline 5 & Tulungagung(Jatim) & Koi & 55 & + \\
\hline 6 & Tulungagung(Jatim) & Koi & 55 & + \\
\hline 7 & Kedir (Jatim) & Koi & 59 & + \\
\hline 8 & Kedir(Jatim) & Komet & 59 & + \\
\hline 9 & Semarang(Jateng) & Komet & 59 & + \\
\hline 10 & Semarang(Jateng) & Koi & 59 & + \\
\hline 11 & Magelang(Jateng) & Mas & 59 & + \\
\hline 12 & Magelang(Jateng) & Koi & 59 & + \\
\hline 13 & Semarang(Jateng) & Koi & 59 & + \\
\hline 14 & Magelang(Jateng) & Mas & 59 & + \\
\hline 15 & Blitar (Jatim) & Koi & 59 & + \\
\hline 16 & Blitar (Jatim) & Koi & 59 & + \\
\hline 17 & Semarang(Jateng) & Koi & 59 & + \\
\hline 18 & Magelang(Jateng) & Koi & 59 & + \\
\hline 19 & Tulungagung(Jatim) & Koi & 55 & + \\
\hline 20 & Tulungagung(Jatim) & Koi & 55 & + \\
\hline
\end{tabular}

elektroforesis pemeriksaan PCR diperoleh fragmen DNA di 2000 bp, sehingga secara Molekuler semua organ sampel yang digunakan pada penelitian ini menunjukkan positif terinfeksi Myxobolus sp dapat dilihat tabel 3.

Tabel 3. Temperatur annealing yang optimum yang positif terinfeksi Myxobolus sp. pada Ikan cyprinid di wilayah Jawa Timur (Blitar, Kediri dan Tulungagung) dan Jawa Tengah (Semarang dan Magelang).

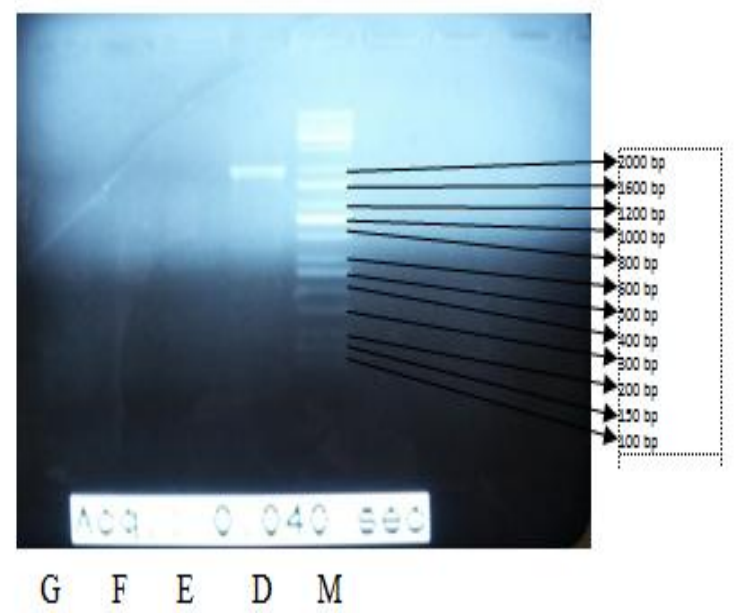

Gambar 5. Elektroforesis suhu Gradient. M. Marker; D. Anneling $59,8{ }^{\circ} \mathrm{C}$; E. Anneling $58,7^{\circ} \mathrm{C}$; F. Anneling $57,3{ }^{\circ} \mathrm{C}$; G. Anneling $56,2^{\circ} \mathrm{C}$. 

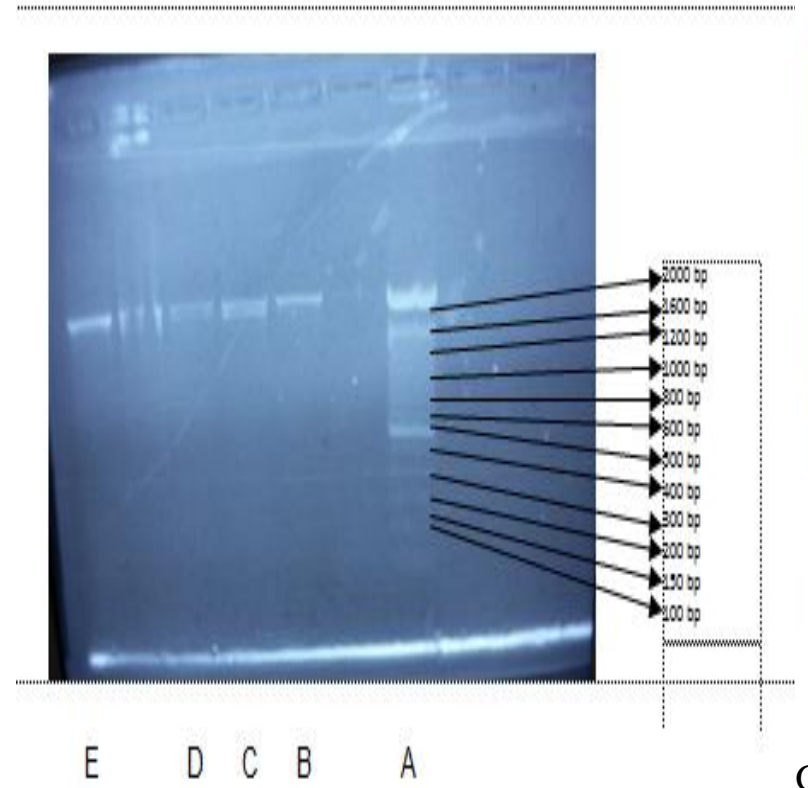

Gambar 6. Elektroforesis produk PCR pada suhu annealing $55^{\circ} \mathrm{C}$. A. Marker; B. Sampel 5; C. Sampel 6 ; D. Sampel 19; E. Sampel 20.

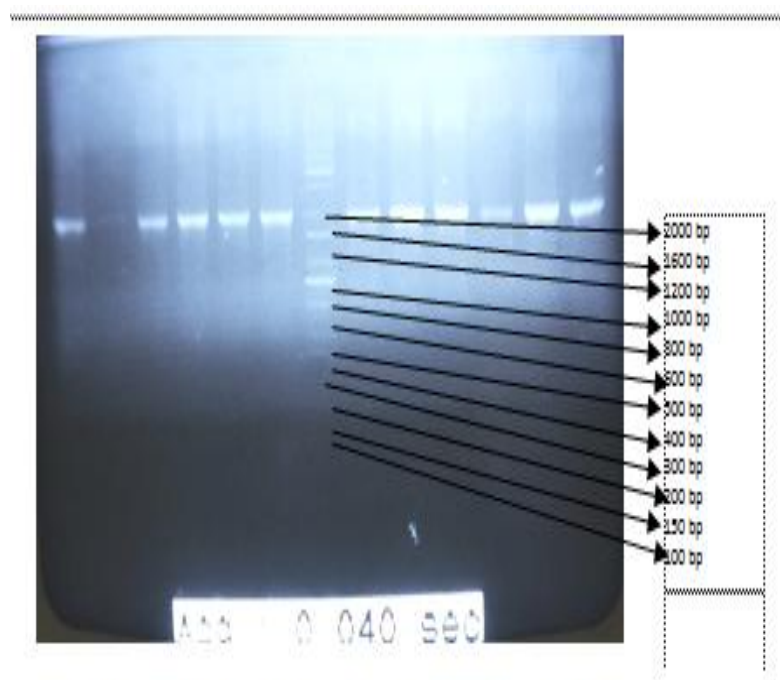

\section{KESIMPULAN}

Pengamatan Myxobolus yang menginfeksi ikan cyprinid, secara wet mount hanya dapat digunakan untuk mengidentifikasi berdasarkan morfologi dan morfometri hingga tingkat genus.

Nodul Myxobolus menyebabkan pada insang yang berwarna putih atau kemerahan dan memenuhi rongga insang sehingga operculum tidak dapat menutup dengan sempurna, gerakan ikan tidak aktif, sisik geripis dan warna tubuh agak pucat/gelap.

Berdasarkan hasil pemeriksaan PCR diperoleh fragmen DNA di 2000 bp, sehingga secara Molekuler semua organ sampel yang digunakan pada penelitian ini menunjukkan positif terinfeksi Myxobolus sp

Gambar 7. Elektroforesis produk PCR pada suhu annealing $59{ }^{\circ} \mathrm{C}$. A. Sampel 1; B. Sampel 2; C. Sampel 3 ; D. Sampel 4; E. Sampel 7; F. Sampel 8; G. Marker; H. Sampel 9; I. Sampel 10; J. Sampel 11; K. Sampel 12; L. Sampel 13; M. Sampel 14.

\section{SARAN}

Pengamatan Myxobolus yang menginfeksi famili cyprinidae, secara wet mount berdasarkan morfologi, morfometri dan metode PCR dapat dijadikan data pendukung bahwa jenis Myxobolus tersebut hingga tingkat genus, sehingga dengan metode PCR 
ini dapat dilakukan dengan uji lanjutan yaitu proses sekuensing hingga tingkat sepesies.

\section{UCAPAN TERIMA KASIH}

Ucapan terima kasih penulis sampaikan kepada Fakultas Bioteknologi Perikanan dan Kelautan Universitas Airlangga yang telah memberikan dukungan dan arahannya atas terselesaikannya penelitian ini.

\section{DAFTAR PUSTAKA}

Afrianto, E dan Liviawaty, E., 1992. Pengendalian Hama dan Penyakit Ikan. Kanisius Yogyakarta : 88 hal.

Alvin C. and Matt J. Griffin, 2010. Molecular Characterization and Histopathology of Myxobolus koi Infecting the Gill of a Koi,Cyprinus carpio, with an Amende Morphological Description of the Agent.Journal of Parasitology. 96:116-124

Anonim, 2010. Keputusan Menteri Kelautan dan Perikanan No: KEP.03/MEN/2010, Tentang Penetapan Jenis-Jenis Hama dan Penyakit Ikan Karantina, Golongan, Media Pembawa dan Sebarannya.

Anonimous, 2006. QIAGEN, DNeasy Blood and Tissue Handbook.

Anonimous. SNI 7547,2009. Badan Standarisasi Nasional Jakarta.

Anshary H, 2008. Modul Pembelajaran Berbasis Student Center Learning (SCL) Mata Kuliah Parasitologi Ikan.

Aquavetplan. 2005. Australian Aquatic Veterinary Emergency Plan. Edition 1.0. Primary Industries Ministerial Council. Canberra. Page 11.

BKIPM. 2014. Peta Daerah Sebar Hama dan Penyakit Ikan Karantina (HPIK) tahun 2014. Balai Karantina Ikan
Pengendalian Mutu dan Keamanan Hasil Perikanan Kelas I Surabaya I. Kementerian Kelautan dan Perikanan Jakarta.

Camus A.C. and Griffin M.J., 2010, Molecular Characterization and Histopathology of Myxobolus koi Infecting The Gills of a Koi, Cyprinus carpio, with an Amanded Morphological Description of The Agent, J. Parasitol., 96(1): 116-124.

Cannon, R.M. 2001. Sense and sensitivitydesigning surveys based on an imperfect test. Prev Vet Med. 49:141163.

Crawshaw M. T., and Sweeting R.A.,. 1986, Myxobolus koi Kudo, 1919: A New Record for Britain, Journal of Fish Diseases 9: 465-467.

Dana D. and Maskur, 1986, Susceptibility of Common Carp Fry (Cyprinus carpio L) to Infection by gill and Muscle Myxosporea, Improvement of Inland Aquaculture. Nodal Center for International Programme, Tokyo University of Agriculture.

Dana, D. \& Maskur. 1991. Susceptibility of Common Carp Fry (Cyprinus carpio, L.) to Infection by Gill and Muscle Myxosporea. Improvement of Inland Aquaculture. Nodai Centre of International Programme. Tokyo University of Agriculture.

Darmo Handoyo dan Ari Rudiretna, 2001.

Prinsip Umum dan Pelaksanaan Polymerase Chain Reaction (PCR) Pusat Studi Bioteknologi - Universitas Surabaya. Unitas, Vol. 9, No. 1

Djajadiredja RTH, Panjaitan A, Rukyani A, Sarono D, Satyani, Supriyadi H. 1982. Fish quarantine and fish disease in Southeast Asia. Report of a workshop. Jakarta. 19-21pp.

Effendy, H. 1993. Mengenal Beberapa Jenis Koi. Kanisius. Jakarta.

Eiras, J. C., K. Molnar dan Y. S. Lu. 2005. Synopsis of the Species of Myxobolus Bütschli, 1882 (Myxozoa 
: Myxosporea : Myxobolidae). Syst Parasitol, 61: 1-46.

El-Matbouli, A. and R.W. Hoffmann. 1989. Experimental Transmission of Two Myxobolus spp. Institu fur Zoologie und Hydrobiologie der Universitat Munchen, Kaulbachstrasse 37. Parasitology Research. Federal Republic of Germany. Developing Bisporogeny Via Tubificid Worms. 1 Hal.

Eszterbauer E, Benko M, Dan A, Molnar K,. 2001. Identification of Fish parasitic Myxobolus (Myxosporea) species using a combined PCR-RFLP Method,Veterinary Medical Research Institute Hungarian.

Farmer, J. N. 1980. The Protozoa. Introduction to Protozoology. The C.V. Mosby Company, St. Louis.

Glick BR dan Pasternak J.,J. 1998. Molecular biotechnology: Principles and aplication of recombinant DNA. Second edition. ASM Press, Washington.

Gul, A., M. Yilmaz, A. Kuscu and S. Benzer. 2010. Feeding Properties of Common Carp Cyprinus carpio L., 1758) Living in Hirfanli Dam Lake. Kastamonu Edu J, 18 (2) : 545-556.

Handajani, R. 2003. DNA Sekuensing. Kursus Biologi Molokuler. Gramik FK Unair. Surabaya, 7 Juni 2003.

Hobir Obing. 2006. Kajian morfologi

Myxobolus sp. pad ikan Mas (Cyprinus carpio). Thesis of Master degree. Yogyakarta. Gadjah Mada University.

Hoffman G.L. and O'Grodnick Y.J, 1977, Control of Whirling Disease (Myxosoma cerebralis): Effects of Chlorine, J. Fish Biol., 10:175-179.

Hoshina T., 1952, Notes on Some Myxosporidian Parasites of Fishes of Japan, Journal of Tokyo University of Fisheries 39: 69-89.

Kallert, D. M. 2006. Life Cycle Studies and Transmission Mechanisms of Myxozoan Parasites. Dissertation.
Friedrich Alexander Universität. p. 96-115.

Karandashova S., 2008, The Introduction of Myxozoan Parasites Through The Release of Feeder Goldfish (Carassius auratus), Honors Baccalaureate Thesis of Science in Microbiology, Oregon State University.

Kent, M. L. 1992. Disease of Seawater Netpen-Reared Salmonid Fishes the Pacific Northwest. Department of Fisheries and Oceans. Nanaimo. pp. 36.

Kent, M. L., Andree, K. B., Bartholomew, J. L., El-Matbouli, M., Desser, S. S., Delvin, R. H., Feist, S. W., Hedrick, R. P., Hoffmann, R. W., Khattra, J., Hallett, S. L., Lester, R. J. G., Longshaw, M., Palenzula, O., Siddall, M. E. and Xiao, C. (2001): Recent advances in our knowledge of the Myxozoa. J. Eukaryot. Microbiol. 48, 395-413.

Kim J.H. 2002. Parasitic Infections in Live Freshwater Tropical Fishes Imported to Korea. Dis Aquat Organ 22, 52, 169-73.

Kudo R., 1977, Protozoology, 5th ed., Publisher Illinois USA, p: 775 - 795.

Larkin, M.A., Blackshields, G., Brown, N.P., Chenna, R., McGettigan, P.A., McWilliam, H., Valentin F., Wallace, I.M., Wilm, A., Lopez, R., Thompson, J.D., Gibson, T.J. \& Higgins, D.G. 2007. ClustalW and ClustalX version 2. Bioinformatics 23, 2947-2948.

Levine N.D., Corliss J.D., Cox F.E.G., Deroux G., Grain J., Honigberg B.M., Leedale G.F., Loeblich III A.R., Lom J., Lynn D., Menfeld E.G., Page F.C., Polyansky G., Vavra V. and Wallace F.G., 1980, A Newly Revised Classification of The Protozoa, J. Protozool 27(1):37-58.

Lom J, Dyková I (1992) Protozoan parasites of fishes. Elsevier Science Publishers, New York Longshaw M, Feist SW, Canning EU, Okamura.

Lowers J.M. and Bartholomew J.L., 2006, "Detection of Myxozoan Parasites in 
Oligochaetes Imported as Food for Ornamental Fish" Journal of Parasitology pp. 84-91.

Lu'lu'in, H., Devi, N. A., Mahasri, G. And Kusdarwati, R. (2012) The relation of Myxobolus koi investation degree to the number of spore and the destruction degree of carp (Cyprinus carpio L.) intestine. $J$ Aq. Fish Health. 1:2.

Mahy., Brian, W.J.and Marc, H.V van Regenmortel. 2010. Desk Encyclopedia of General Virologi. Published by Academic Press Elsevier Ltd. Malole, M.B., 1988 Virology. Pusat Antar Universitas. IPB.p 113

Molnar, K.(1994): Comments on the host, organ and tissue specificity of fish myxosporeans and on the types of their intrapiscine development. Parasit. Hung 27, 5-20.

Mulyana, R. I. Riadi, S. L. Angka, dan A. Rukhyani. 1990. Pemakaian Sistem Saringan Untuk mencegah infeksi parasit pada benih ikan (Cyprinus carpio L.) di kolam. Balai Penelitian Perikanan Air Tawar, Pusat Penelitian dan Pengembangan Perikanan, Badan Penelitian dan Pengembangan Pertanian. Bogor. Hal. 169-173.

Newton, C.R. and A. Graham. 1994. PCR. UK: Bios Scientific Publisher.

Noga, E. J. 2010. Fish Disease. 2nd Edition. Wiley Blackwell. USA. pp. 242.

Paperna, I. 1992. Diseases Caused by Parasites in The Aquaculture of Warm Water Fish. Annual Reviewof Fish Diseases 1. 155-194.

Pavlovskii F.N., 1962, Key to Parasite of Freshwater Fish of The USSR, Israel Programme from Scientific Translation, Yerussalem.

Purwaningsih, I. 2013. Identifikasi Ektoparasit Protozoa pada Benih Ikan Mas (Cyprinus carpio Linnaeus, 1758) di Unit Kerja Budidaya Air Tawar (UKBAT) Cangkringan Sleman DIY. Skripsi. Biologi. Fakultas Sains dan
Teknologi. UIN Sunan Kelijaga.Yogyakarta. 2-3 hal.

Rukyani, A. 1978. Two species of myxobolidae(Myxosporidia) from fresh water fisher in Java. Pew.Lemb. Penel. Perik. Dar, 1:24-25.

Rukyani, A. 1990. Histopathological Changes in the Gill of Common Carp (Cyprinus carpio L.) Infected with the Myxoosporean Parasite Myxobolus koi Kudo,1920, Asian Fisheries Society, Manila, Philippines 337-341.

Saanin, H. 1984. Taksonomi dan Kunci Idnetifikasi I. Binacipta. Bandung. 245 Hal.

Sachlan M. 1952. Notes on parasites of freshwater fishes in Indonesia. Contrib Intl Fish Res Stat 2:1-60.

Saitou, N \& M. Nei.1987. The Neighbor Joining Method: A New Method for Reconstructing Phylogenetic Trees. Molecular Biology and Evolution. 4: 406-425.

Sambrook J., Fritsch, E.F. and Maniatis, T. 1989. Molecular Cloning: a Laboratory Manual. 2nd ed. N.Y., Cold Spring Harbor Laboratory, Cold spring Harbor Laboratory Press.

Schlegel M., Lom J., Stechmann A., Bernhard D., Leipe D., DykovaÂ I., Sogin M.L., 1996, Phylogenetic Analysis of Complete Small Subunit Ribosomal RNA Coding Region of Myxidium Lieberkuehni: Evidence that Myxozoa are Metazoa Related to the Bilateria. Archiv Fur Protisten Kund 147:1 \pm 9 .

Senapin, S., Phewsaiya, K., Briggs, M., Flegel, T.W. 2007. Outbreaks of infectious myonecrosis virus (IMNV) in Indonesia confirmed by genome sequencing and use of an alternative RT-PCR detection method. Aquaculture, 266:32-38. 
Shukla, S.N. and V. Patel. 2013. Studies on Food and Feeding Behaviour of Cyprinus carpio and Their Gastrosomatic Index from Govindgarh Lake, Rewa (M.P.), India. Online International Interdisciplinary Res J. 3 : 116-122.

Shuzo Equsa, 1992, Infectious Diseases of Fish, Amerind Pub.Co.

Sulistyaningsih, Erma. 2007. Polymerase Chain Reaction (PCR): Era Baru Diagnosis dan Manajemen Penyakit Infeksi Biomedis, Vol. 1.

Supriyadi, H. 2004. Membuat Ikan Hias Tampil Sehat Dan Prima. Agro Media Pustaka. Jakarta.

Susanto dan Rochdianto A. 1997. Kiat Budidaya Ikan Mas di Lahan Kritis. PT Penebar Swadaya. Depok.

Susanto, H. 2000. Koi. Penebar swadaya. Jakarta.

Susanto, 2007. Kiat Budidaya Ikan Mas di Lahan Kritis. Penebar Swadaya. Jakarta.

Susanto, H. 2008. Panduan Memelihara Koi. Penebar Swadaya. Jakarta. 107 hal.

Wijaya, T. 2011. Nilai Ekspor Ikan Hias Bakal Naik 10\%. Republika Indonesia.Diunduh pada tanggal 30 Januari 2013 dari http://www.republikaindonesia.com.

Tamura K, Peterson D, Peterson N, Stecher G, Nei M, Kumar S (2011). MEGA5: molecular evolutionary genetics analysis using maximum likelihood, evolutionary distance, and maximum parsimony methods. Mol Biol Evol 28:2731-2739. doi:10.1093/molbev/msr121.

Woo, P. T. K., D. W. Bruno, and L. H. S. Lim. 2001. Diseases and Disorders of Finfish In Cage Culture. CAB International, New York USA. 250251.

Yokoyama H., Inoue D., Kumamaru A. and Wakabayashi H., 1997, Myxobolus koi (Myxozoa: Myxosporea) Forms Largeand Small-Type 'Cysts' in The Gills of
Common Carp. Fish Pathology 32: 211-217.

Yuwono, T.2006. Teori dan Aplikasi Polymerase Chain Reaction. Andi Offset. Yogyakarta.

Zhang1,2, H Yokoyama, J G Wang, A H Li1, $\mathrm{X} \mathrm{N}$ Gong, A Ryu-Hasegawa, M Iwashita and K Ogawa (2010). Utilization of tissue habitats by Myxobolus wulii Landsberg \& Lom, 1991 in different carp hosts and disease resistance in allogynogenetic gibel carp: redescription of $M$. wulii from China and Japan. Journal of Fish Diseases 33:57-68 